\title{
Determinan Kinerja Sektor Publik: Dimoderasi Sistem Pengendalian Intern pada Puskesmas BLUD di Kota Pekanbaru
}

\author{
Mai Siska \\ Ria Nelly Sari \\ Yesi Mutia Basri \\ Program Studi Magister Akuntansi, Universitas Riau \\ Pekanbaru, Indonesia \\ yesimutia@gmail.com
}

\begin{abstract}
This research is the result of empirical studies that show facts in explaining the properties that occur in the object under study through statistical principles. The purpose of this study was to examine and analyze the factors that influence the performance of public health centers in Pekanbaru city such as BLUD financial management, quality of human resources and utilization of information systems with internal control as moderating variables. The object of this research is all BLUD puskesmas in Pekanbaru city. The research method was carried out by a survey conducted in June 2020. Respondents in this study were the Head of the Puskesmas, the Head of Administration, the BLUD Financial Coordinator, the Admissions Treasurer, the Expenditure Treasurer and the Information System Coordinator in the puskesmas, totaling 120 respondents. The results of multiple regression analysis show that BLUD financial management, quality of human resources, and utilization of information systems have a positive effect on the performance of puskesmas and are strengthened by internal controls. This research has implications for public sector organizations that implement BLUD financial management such as public health centers as motivation and evaluation materials related to performance achievement through the process of improving BLUD financial management, quality of human resources, utilization of information systems and internal control.
\end{abstract}

Keywords: Financial Management of regional public service agencies, quality of human resources, utilization of information systems, organizational performance of local public service agencies

\footnotetext{
ABSTRAK

Penelitian ini merupakan hasil dari studi empiris yang menunjukkan fakta-fakta dalam menjelaskan sifat yang terjadi pada objek yang diteliti melalui prinsip-prinsip statistik. Tujuan penelitian ini adalah untuk menguji dan menganalisis faktor-faktor yang mempengaruhi kinerja puskesmas BLUD di kota Pekanbaru seperti pengelolaan keuangan BLUD, kualitas SDM dan pemanfaatan sistem informasi dengan pengendalian internal sebagai variabel moderasi. Objek dari penelitian ini adalah seluruh puskesmas BLUD yang ada di kota Pekanbaru. Metode penelitian dilakukan dengan survey yang dilakukan pada bulan Juni 2020 . Responden dalam penelitian ini adalah Kepala Puskesmas, Kepala Tata Usaha, Koordinator Keungan BLUD, 
Bendahara Penerimaan, Bendahara Pengeluaran dan Kordinator Sistem Informasi di lingkungan puskesmas yang berjumlah 120 responden. Hasil analisis regressi berganda menunjukan bahwa pengelolaan keuangan BLUD, kualitas SDM, dan pemanfaatan sistem informasi berpengaruh positif terhadap kinerja puskesmas dan diperkuat dengan adanya pengendalian internal. Penelitian ini mempunyai implikasi kepada organisasi sektor publik yang menerapkan pengelolaan keuangan BLUD seperti puskesmas sebagai bahan motivasi dan evaluasi terkait pencapaian kinerja melalui proses peningkatan pengelolaan keuangan BLUD, kualitas SDM, pemanfaatan sistem informasi dan pengendalian internal.

Kata Kunci: Pengelolaan Keuangan BLUD, Kualitas SDM, Pemanfaatan Sistem Informasi, Kinerja Puskesmas BLUD

\section{PENDAHULUAN}

Organisasi sektor publik merupakan entitas yang berhubungan dengan usaha menghasilkan barang dan jasa untuk memenuhi kebutuhan publik (Mardiasmo, 2011). Fungsi utama organisasi sektor publik yang memberikan pelayanan kepada publik telah menjadi perhatian berbagai pihak. Oleh karenanya organisasi sektor publik dituntut untuk dapat memberikan pelayanan yang baik kepada masyarakat. Maka dari itu kinerja organisasi sektor publik menjadi perhatian utama masyarakat.

Salah satu organisasi sektor publik adalah organisasi kesehatan. Rumah sakit ataupun puskesmas merupakan organisasi sektor publik yang menyelenggakan pelayanan kesehatan tingkat dasar milik pemerintah.

Kota Pekanbaru adalah salah satu kota yang peduli dengan penyelenggaraan pelayanan kesehatan yang bermutu. Selain memiliki Rumah sakit Daerah, kota Pekanbaru juga memiliki Pusat Kesehatan Masyarakat (Puskesmas). Berdasarkan Peraturan Walikota Pekanbaru No. 50 Tahun 2016 tanggal 5 Januari 2016 pemerintah kota Pekanbaru melakukan peningkatan status puskesmas dari non BLU menjadi BLUD, yaitu menetapkan 20 BLUD Puskesmas dari 21 Puskesmas di Kota Pekanbaru.

Perubahan status menjadi BLUD ini bertujuan untuk meningkatkan kinerja Puskesmas agar lebih efektif dan efisien. Permendagri No. 79 Tahun 2018 tentang BLUD menjelaskan bahwa organisasi pemerintah yang menerapkan pengelolaan keuangan BLUD wajib untuk mengukur kinerja yang meliputi kinerja keuangan dan pelayanan serta meningkatkan kinerjanya.

Walaupun implementasi BLUD telah dilaksanakan dalam beberapa tahun, namun kinerja Puskesmas di Kota Pekanbaru belum menunjukkan kinerja yang optimal. Hal Ini dapat terlihat dari capaian kinerja keuangan puskesmas BLUD kota Pekanbaru terhadap realisasi anggaran belum mencapai target 100\% pada tahun 2016 - 2018. Walaupun terjadi peningkatan realisasi anggaran, namun belum mencapai 100 persen.

Realisasi penyerapan anggaran kegiatan peningkatan pelayanan BLUD Puskemas dapat dilihat pada grafik di samping : 


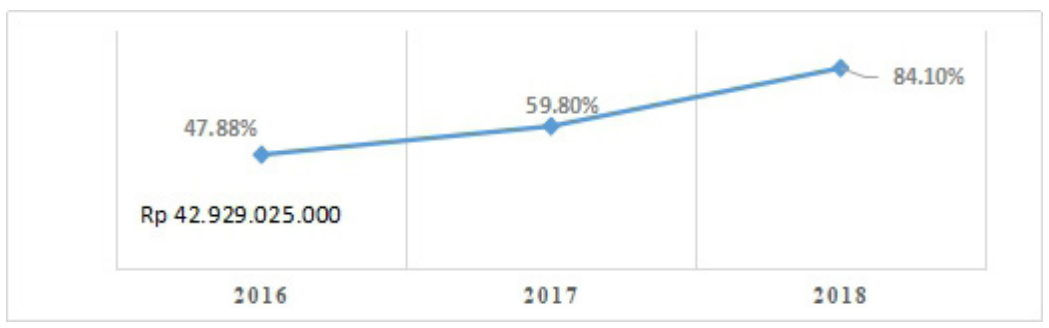

Sumber : Lakip Dinas Kesehatan Kota Pekanbaru 2019

Gambar 1 Realisasi Anggaran \& Pagu Anggaran Puskesmas BLUD

Sekota PekanbaruTahun 2016-2018

Berdasarkan grafik diatas dapat dijelaskankan bahwa pada tahun 2016 hingga tahun 2018 anggaran BLUD Puskesmas di kota Pekanbaru menurun setiap tahunnya dimana pada tahun 2016 anggaran BLUD Puskesmas yaitu Rp 42.929.025.00, 2017 yaitu 38.310.847.000 dan 2018 yaitu 29.598.840.747. Sedangkan realisasi anggaran BLUD Puskesmas di kota Pekanbaru meningkat setiap tahunnya dimana pada tahun 2016 realisasi anggaran yaitu 47.88\%, 2017 yaitu 59.80\% dan 2018 yaitu 84.10\%. Dalam tiga tahun melaksanakan pengelolaan keuangan BLUD Puskesmas di Kota Pekanbaru belum mampu untuk menyerap anggaran BLUD yang telah direncanakan berdasarkan target $100 \%$.

Selain kinerja keuangan, pencapaian target kinerja Standar Pelayanan Minimum (SPM) juga belum memenuhi target. Pada tahun 2018 sebanyak 6 kegiatan berada dibawah bawah target yaitu < 67\%. Diantara kegiatan yang belum mencapai target adalah pelayanan kesehatan balita, usia lanjut, penderita hipertensi dan pelayanan kesehatan pada usia produktif. (LKPD 2018 Dinas Kesehatan Kota Pekanbaru)

Realita lainya dari pengelolaan keuangan BLUD puskesmas dikota Pekanbaru berdasarkan wawancara dengan Kepala Sub Bagian Anggaran Dan Program Dinas Kesehatan Kota Pekanbaru tidak tercapainya indikator kinerja SPM dan realiasi anggaran dipicu oleh ketidak cermatan Sumber Daya Manusia (SDM) dalam menyusun Rencana Bisnis Anggaran (RBA) Puskesmas. Dalam hal ini terkait dengan perencanaan anggaran berbasis kinerja. Permendagri No. 13 Tahun 2006 tentang pengelolaan keuangan daerah dijelaskan anggaran berbasis kinerja merupakan suatu pendekatan dalam penyusunan anggaran dengan memperhatikan keterkaitan antara pendanaan dengan keluaran yang diharapkan dari kegiatan dan hasil serta manfaat yang diharapkan termasuk efisiensi dalam pencapaian hasil dan keluaran tersebut.

Belum optimalnya kinerja pada organisasi sektor publik telah menjadi topik yang menarik. Berbagai penelitian terdahulu telah meneliti kinerja pada sektor publik (misalnya Budiarso et al., (2015), Areva, (2012) dan Dewi, 2014). Penelitian tersebut mengusulkan pengukuran kinerja keuangan dan non keuangan pada Rumah sakit. Penelitian lainnya meneliti mengenai faktor yang mempengaruhi kinerja pada sektor publik pada universitas misalnya (Nurani et al., 2020), (Sukesti, 2010). Sebagian besar penelitian mengenai kinerja pada organisasi sektor publik dilakukan pada organisasi Pemerintah seperti (Hendra, 2018), (Rulyanti et all, 2018) dan (Sulina et all, 2017).

Determinan Kinerja Sektor Publik: Dimoderasi Sistem Pengendalian Intern pada Puskesmas BLUD 
Penelitian mengenai kinerja pada sektor kesehatan sebagian besar dilakukan pada Rumah Sakit, dan masih sedikit yang melakukan pada Puskesmas, terutama pada Puskesmas yang telah memiliki prediket Badan Layanan Umum. Badan Layanan Umum (BLU) merupakan organisasi publik yang memiliki semi otonomi dalam pengelolaan keuangan bertujuan untuk memberikan pelayanan publik yang berkualitas mengedepankan kinerja melalui usaha penerapan praktek bisnis yang sehat dalam pengelolaan keuangannya (IAI,2017).

Pengelolaan keuangan BLU/BLUD merupakan salah satu faktor yang menentukan pencapaian kinerja pada organisasi yang menerapkan BLU. Hal ini didukung oleh Hasil penelitian, (Liawan, 2018), (Ernitati, 2016) dan (Puspadewi, 2015) menunjukkan terdapat pengaruh positif pengelolaan keuangan BLU/BLUD terhadap kinerja. Namun penelitian (Ratih et all, 2011) dan (Asse, 2016) tidak berpengaruh.

Menurut (Anggarini Yunita dan B. Hendra Puranto, 2010) selain pengelolaan keuangan terdapat instrumen lain yang perlu diperhatikan dalam melaksanakan kebijakan yaitu kualitas SDM. SDM yang tidak berkualitas yaitu SDM yang tidak memiliki kompetensi dan keterampilan tidak akan dapat menyelasaikan pekerjaan secara efektif dan efesien, hal ini dapat menyebakan rendahnya kinerja dikarenakan pekerjaan yang dihasilkan tidak tepat waktu, terjadi pemborosan waktu dan sumber daya organisasi. Penelitian (Noor, 2015) menyatakan kualitas SDM berpengaruh positif dan paling dominan terhadap kinerja BLUD Puskesmas. Namun penelitian (Fahdi et all, 2015) kualitas SDM tidak berpengaruh.

Faktor lainnya yang tidak kalah penting adalah pemanfaatan sistem informasi.Pemanfaatan Sistem informasi membantu dalam pemrosesan data lebih cepat dan meminimalkan terjadinya kesalahan sehingga dapat meningkatkan kinerja pekerjaan. Hasil penelitian (Susanti, 2014) dan (Fiqra et all, 2016) menyatakan bahwa pemanfaatan sistem informasi berpengaruh positif tehadap kinerja organisasi. Sedangkan penelitian (Oktari, 2011) tidak berpengaruh.

Merujuk pada hasil penelitian sebelumnya, terdapat ketidakkonsis-tenan hasil yang mempengaruhi kinerja puskemas BLUD, diduga terdapat faktor lain yang bersifat situasional yang mempengaruhi hubungan variabel tersebut. Pada penelitian ini peneliti mengajukan sistem pengendalian intern sebagai variabel yang memoderasi hubungan antara pengelolaan BLUD, kompetesi SDM dan pemanfaatan dengan kinerja puskesmas BLUD.

Pengendalian internal dan pengawasan diperlukan dalam pengelolaan keuangan BLUD yang fleksibel agar tidak terjadi penyimpangan dan penyelewengan (Mardiasmo, 2011). Penguatan fungsi pengendalian ini untuk mencapai tujuan dan meminimalkan hal-hal yang mungkin terjadi diluar rencana atau menyimpang. (Lamusu, 2013) menyatakan semakin baik pengendalian internal dalam sebuah organisasi akan mengefektifkan pengelolaan keuangan organisasi sehingga meningkatkan kinerja organisasi.

Berdasarkan uraian diatas penelitian ini bertujuan menguji dan menganalisis pengaruh pengelolaan keuangan BLUD, kualitas SDM dan pemanfaatan sistem informasi terhadap kinerja puskesmas BLUD yang berada di Kota pekanbaru. Penelitian ini juga menguji dan menganalisis peran pengendalian internal sebagai variabel pemoderasi yang memperkuat pengaruh pengelolaan keuangan BLUD, kualitas SDM dan pemanfaatan sistem informasi terhadap kinerja organisasi puskesmas. Penelitian

Penelitian ini juga memiliki keunikan yaitu dilakukan pada Puskesmas yang memiliki status Badan 
Layanan Umum daerah (BLUD) yang masih sedikit dilakukan. Penelitian ini juga berbeda dengan penelitian lainnya yaitu menggunakan moderasi sistem pengendalian intern. Penelitian ini memiliki kontribusi yaitu dapat menjadi masukan dalam menyusun kebijakan dalam meningkatkan kinerja pada Puskesmas BLUD. Moderasi pengendalian intern pada kinerja BLUD diteliti oleh (Sandria et al., 2020), namun penelitian tersebut menekankan pada efektivitas pengelolaan BLUD.

\section{TELAAH LITERATUR DAN PENGEMBANGAN HIPOTESIS}

\section{Pengaruh Pengelolaan Keuangan BLUD Terhadap Kinerja Puskesmas BLUD}

Menurut (Restianto, 2015) organisasi sektor publik setelah menerapkan pengelolaan keuangan BLUD membuat perjanjian kinerja yang dilakukan antara kepala daerah dan pimpinan BLUD. Selain itu, adanya penghargaan berupa pemberian remunerasi kepada para pejabat BLUD berdasarkan indikator penilaian yang ditetapkan, serta pengadaan barang dan jasa yang tidak mengikuti Peraturan Presiden Perpres yaitu dengan didasarkan atas kebijakan pimpinan BLUD. Hal ini dapat mempengaruhi pimpinan atau pegawai dalam meningkatkan kinerjanya. Jadi dengan adanya BLUD ini, maka pengelolaan keuangan di puskesmas dapat dilakukan secara mandiri dan langsung menjadi pendapatan masing-masing puskesmas, sehingga puskesmas tersebut bisa mencari dan menyusun anggarannya sendiri. Dengan demikan, penerapan pengelolaan keuangan BLUD dapat meningkatkan kinerja puskesmas dalam memberikan pelayanan kepada masyarakat.

Penelitian yang (Puspadewi, 2015), (Budiarso et al., 2015) didapatkan hasil bahwa pengelolaan keuangan daerah berpengaruh terhadap kinerja pemerintah daerah. Berdasarkan uraian tersebut, diajukan hipotesis penelitian sebagai berikut:

\section{$\mathbf{H}_{1}$ : pengelolaan keuangan BLUD berpengaruh positif terhadap kinerja puskesmas BLUD di kota Pekanbaru}

\section{Pengaruh Kualitas SDM Terhadap Kinerja Puskesmas BLUD}

Wahyuni (2010) mengatakan bahwa dalam merespon perubahan kebijakan terkait penerapan pola pengelolaan keuangan BLU diperlukan SDM yang berkualitas. Dengan SDM yang berkualitas diharapkan dapat melaksanakan tugas dengan baik berdasarkan visi, misi, dan tujuan organisasi. Dengan demikian kinerja organisasi BLU dapat ditingkatkan.

Penelitian (Wicaksono, 2011) dan (Noor, 2015) membuktikan SDM berpengaruh terhadap kinerja BLU, Sedangkan penelitian(Fahdi et al., 2015) menemukan kualitas SDM tidak berpengaruh terhadap kinerja BLU Universitas Riau. Berdasarkan penjelasan di atas masih terdapat perbedaan hasil mengenai peran kualitas sumber daya manusia terhadap kinerja. Oleh karena itu, diajukan hipotesis sebagai berikut:

\section{$\mathrm{H}_{2}$ : Kualitas SDM berpengaruh positif terhadap kinerja puskesmas BLUD di kota pekanbaru}

\section{Pengaruh Pemanfaatan Sistem Informasi Terhadap Kinerja Puskesmas BLUD}

Perkembangan sistem informasi tidak hanya dimanfaatkan pada organisasi bisnis tetapi juga pada organisasi sektor publik, termasuk pemerintahan. Dalam Peraturan Pemerintah No. 56 Tahun 2005 "tentang 
Sistem Informasi Keuangan Daerah disebutkan bahwa untuk menindaklanjuti terselenggaranya proses pembangunan yang sejalan dengan prinsip tata kelola pemerintahan yang baik Good Governance, pemerintah dan pemerintah daerah berkewajiban untuk mengembangkan dan memanfaatkan kemajuan teknologi informasi guna meningkatkan kemampuan pengelolaan keuangan daerah, dan menyalurkan Informasi keuangan daerah kepada stakeholder". Pemerintah perlu mengoptimalisasi pemanfaatan sistem informasi untuk membangun jaringan sistem informasi manajemen dan proses kerja yang memungkinkan pemerintahan bekerja secara terpadu dengan menyederhanakan akses antar unit kerja.

Penelitian Susanti (2014) memperlihatkan bahwa sistem informasi berpengaruh signifikan tehadap kinerja organisasi. Lebih lanjut menurut (Kadir, 2014) bahwa "sistem informasi memberikan nilai tambah terhadap proses, produksi, kualitas, manajemen, pengambilan keputusan dan pemecahan masalah serta keunggulan kompetitif yang tentu saja sangat berguna bagii kegiatan bisnis". Peningkatan penggunaan sistem informasi juga tidak terlepas dari perhatian manajemen dalam perusahaan terhadap betapa pentingnya manajemen informasi. Sehingga diharapkan bahwa sistem informasi dapat meningkatkan kinerja organisasi.

\section{$\mathbf{H}_{3}$ : Sistem informasi berpengaruh positif terhadap kinerja puskesmas BLUD di Kota Pekanbaru}

\section{Pengaruh Pengelolaan Keuangan BLUD Terhadap Kinerja Kinerja Puskesmas BLUD dimoderasi oleh Pengendalian Internal}

Sistem Pengendalian Internal Pemerintah SPIP yang diatur dalam PP No. 60 Tahun 2008 mendefinisikan "pengendalian internal sebagai sistem pengendalian/ pengawasan organisasi yang meliputi semua metode dan ketentuan yang terkoordinasi yang dianut dalam suatu organisasi untuk melindungi harta miliknya, mencek kecermatan dan keandalan data akuntansi, meningkatkan efisiensi usaha dan mendorong di taatinya kebijakan manajemen yang telah digariskan".

Hubungan antara pengelolaan keuangan BLUD terhadap kinerja organisasi akan semakin kuat atau sebaliknya semakin lemah dengan adanya dengan adanya pengendalian internal.

Adanya pemberian kewenangan dan keleluasaan dalam mengelola keuangan kepada pengelola BLUD menyebabkan keharuskan dilakukan pengawasan agar tidak terjadi penyimpangan dan penyelewengan. Oleh karena itu pemberian kewenangan dan keleluasaan tersebut harus diikuti dengan pengawasan pengendalian yang kuat. Penguatan fungsi penegendalian dilakukan dengan melalui pembuatan sistem pengendalian internal yang efektif.

Penelitian (Kemala \& Taufik, 2013) menunjukkan bahwa pengendalian intern berpengaruh terhadap kinerja sektor publik. (Misfikar, 2018) menunjukkan bahwa pengendalian internal mampu menjadi variabel pemoderasi antara hubungan pola pengelolaan keuangan BLUD dengan kinerja organisasi. Berdasarkan uraian di atas, hipotesis dapat dirumuskan sebagai berikut:

\section{$\mathrm{H}_{4}$ : Pengendalian internal memoderasi hubungan antara pengelolaan keuangan BLUD dengan pada kinerja puskesmas BLUD kota Pekanbaru}

Pengaruh Kualitas SDM Terhadap Kinerja Kinerja Puskesmas BLUD dimoderasi Pengendalian Internal 
SDM merupakan elemen organisasi yang sangat penting, oleh karena itu harus dipastikan SDM dikelola sebaik mungkin agar mampu memberikan kontribusi secara optimal dalam upaya pencapaian tujuan organisasi. Dalam rangka pengelolaan keuangan BLUD, organisasi BLUD harus memiliki kualitas SDM yang didukung dengan latar belakang pendidikan, sering mengikuti pendidikan dan pelatihan, dan mempunyai pengalaman di bidangnya.

Penelitian yang dilakukan (Kemala \& Taufik, 2013) dan (Septiyani et al., 2020) menunjukkan bahwa pengendalian intern berpengaruh terhadap kinerja sektor publik. Berdasarkan penjelasan di atas diajukan hipotesis sebagai berikut:

\section{$\mathbf{H}_{5}$ : Pengendalian internal memoderasi hubungan antara kualitas SDM pada kinerja organisasi puskesmas di kota Pekanbaru.}

\section{Pengaruh Pemanfaatan Sistem Informasi Terhadap Kinerja Puskesmas BLUD dimoderasi Pengendalian Internal}

Mengawasi jalannya pelaksanaan sistem informasi dalam suatu organisasi harus ada satu unit internal yang bersifat independent yaitu Satuan Pengawasan Internal SPI. Menurut Fahdi (2015) SPI berfungsi dan bertugas membantu Direksi dalam memastikan pencapaian tujuan dan kelangsungan usaha

SPI bertanggung jawab kepada pengurus dan badan pengawas yang membawahi tugas pengendalian internal. Keberadaan SPI dalam suatu perusahaan sangat penting dalam rangka melakukan pengawasan dan pengendalian terhadap jalannya sistem informasi teknologi di suatu organisasi serta di taatinya peraturan yang telah ditetapkan oleh organisasi. Berdasarkan hipotesis diatas maka:

\section{$\mathrm{H}_{6}$ : Pengendalian internal memoderasi hubungan antara sistem informasi pada kinerja puskesmas di kota Pekanbaru}

\section{METODE PENELITIAN}

\section{Populasi dan Sampel}

Penelitian ini menggunakan pendekatan kuantitatif dengan populasi 20 puskesmas BLUD di Kota Pekanbaru. Teknik sampling adalah sensus yaitu menggunakan seluruh populasi sebagai sampel. Responden dalam penelitian ini adalah Kepala Puskesmas, Kepala Tata Usaha, Kordinator Keungan BLUD, Bendahara Penerimaan, Bendahara Pengeluaran dan Kordinator Sistem Informasi di lingkungan puskesmas yang berjumlah 120 responden.

\section{Teknik Pengumpulan Data}

Teknik pengumpulan data dalam penelitian ini dilakukan dengan menggunakan metode survei yaitu metode pengumpulan data primer yang menggunakan pernyataan tertulis. Metode survei yang digunakan adalah dengan cara menyebarkan kuisioner kepada responden dalam bentuk pernyataan tertulis. Masingmasing responden diberikan kuisioner dengan jangka waktu pengembalian 3 (tiga) minggu terhitung sejak kuesioner diterima. 


\section{Definisi Operasional}

\section{Kinerja Puskesmas}

Menurut Peraturan Pemerintah No. 58 Tahun 2005, yaitu kinerja merupakan keluaran/ hasil dari kegiatan/ program yang akan atau telah dicapai sehubungan dengan pengguna anggaran dengan kuantitas yang diukur. Selain itu menurut (Mahsun, 2016) Kinerja organisasi adalah suatu alat ukur untuk menilai dan mengevaluasi berhasil atau tidak tujuan suatu organisasi. Adapun indikator kinerja dalam penelitian ini adalah Produktivitas,Kualitas layanan dan Responsivitas

\section{Pengelolaan Keuangan (BLUD) (X1)}

Menurut Pemendagri Nomor 79 Tahun 2018 pengolaan keuangan BLUD adalah pengelolaan keuangan yang memberikan fleksibilitas berupa keluasaan untuk menerapkan praktik-praktik bisnis yang sehat untuk meningkatkan pelayanan kepada masyarakat dalam rangka memajukan kesejahteraan umum dan mencerdaskan kehidupan bangsa. Indikator variabel ini adalah (Pemendagri No. 79 tahun 2018): Perencanaan anggaran,Pelaksanaan anggaran,Pegawai dan remunerasi,Pelaporan dan pertanggungjawaban,Pengawasan dan pembinaan.

\section{Kualitas SDM (X2)}

Fahdi (2015) bahwa kualitas SDM adalah individu dalam organisasi yang memberikan sumbangan berharga pada pencapaian tujuan organisasi. Menurut (Matutina, 2001) kualitas SDM dapat dilihat dari: Pengetahuan knowledge, Keterampilan skill, Abilities.

\section{Pemanfaatan Sistem Informasi (SI)}

Sistem informasi adalah penggunaan teknologi informasi mengubah data menjadi informasi untuk tujuan tertentu. Teknologi adalah alat yang digunakan individu untuk membantu menyelesaikan tugas-tugasnya. Kata teknologi banyak merujuk pada sistem komputer yang terdiri atas perangkat keras, perangkat lunak dan data serta dukungan layanan yang disediakan untuk membantu para pemakai dalam menyelesaikan tugasnya (Widhiyani, 2008:220 dalam Fahdi. M, 2015).

Indikator yang digunakan untuk menilai penggunaan teknologi informasi dalam suatu organisasi adalah: Hardware dan software digunakan, Pengintegrasian tugas dengan TI, Pemeliharaan perangkat TI

\section{Pengendalian Internal (Z)}

COSO (2013:3) mendefinisikan pengendalian internal sebagai proses yang integral dari kegiatan manajemen dasar dalam memberikan keyakinan memadai tentang pencapaian tujuan yang berkaitan dengan operasi, pelaporan, dan kepatuhan. Indikator dari pengendalian internal menurut COSO adalah: Lingkungan pengendalian, Penilaian risiko,Aktivitas pengendalian,Informasi dan komunikasi, Pemantauan

Teknik Analisis Data

Analisis data dilakukan dengan Multiple Regression Analysis untuk pengujian hipotesis 1,2 dan 3 
serta Moderated Regression Analysis (MRA) untuk Pengujian hipotesis 4,5 dan 6 Ghozali (2012) untuk mengidentifikasi dan menganalisis variabel moderating secara lebih detail dapat dilihat berdasarkan kalsifikasi variabel moderasi .

\section{HASIL DAN PEMBAHASAN}

Kuesioner yang disebarkan yaitu sebanyak 120 eksemplar, dimana secara keseluruhan atau 100\% kuesioner kembali. Maka kuesioner yang dapat diolah sebanyak 120 eksemplar. Adapun perincian mengenai pendistribusian dan pengembalian kuesioner responden pada tabel 1 berikut ini.

Tabel 1 Distribusi Dan Pengembalian Kuesioner Responden

\begin{tabular}{clcc}
\hline No & \multicolumn{1}{c}{ Keterangan } & Jumlah (orang) & Persentase (\%) \\
\hline 1. & Kuesioner yang disebarkan & 120 & 100 \\
2. & Kuesioner yang kembali & 120 & 100 \\
& Kuesioner yang tidak kembali & 0 & 0 \\
& Respon date & & $100 \%$ \\
\hline
\end{tabular}

Sumber: Data Olahan (2020)

\section{Analisis Statistik Deskriptif}

Descriptive variabel penelitian yaitu nilai minimum, maximum, mean dan standard deviasi masingmasing variabel penelitian. Deskriptif variable pada penelitian ini dapat dilihat pada tabel dibawah ini.

Tabel 2. Statistik deskriptif

\begin{tabular}{lrrrrr}
\hline & $\mathrm{N}$ & Min & Max & Mean & SD \\
\hline Kinerja Puskesmas $(\mathrm{Y})$ & 120 & 2.67 & 4.00 & 3.34 & 0.313 \\
Pengelolaan Keuangan BLUD $\left(\mathrm{X}_{1}\right)$ & 120 & 3.19 & 4.43 & 3.90 & 0.338 \\
Kualitas SDM $\left(\mathrm{X}_{2}\right)$ & 120 & 3,18 & 5.00 & 4.09 & 0.415 \\
Pemanfaatan Sistem Informasi $\left(\mathrm{X}_{3}\right)$ & 120 & 2.82 & 4.36 & 3.74 & 0.379 \\
Pengendalian Internal $(\mathrm{Z})$ & 120 & 2.40 & 3.70 & 3.10 & 0.254 \\
Valid N (listwise) & 120 & & & & \\
\hline
\end{tabular}

Sumber: Data Olahan , 2020

Dari Tabel 2 dapat dilihat bahwa tanggapan responden terhadap variabel kinerja puskesmas, pengelolaan keuangan BLUD, kualitas SDM, Pemanfaatan Sistem informasi dan pengendalian internal ratarata diatas 3,00 yang berarti bahwa responden Puskesmas BLUD di Kota Pekanbaru memberikan tanggapan terhadap pernyataan variabel penelitian tergolong cukup baik.

\section{Hasil Pengujian Kualitas Data}

Hasil pengujian terhadap kualitas data dapat dilihat pada tabel dibawah ini: 
Tabel 3. Reabilitas Data

\begin{tabular}{|c|c|c|c|c|c|c|}
\hline Variabel & Standar & $\begin{array}{l}\text { Cronbach's } \\
\text { Alpha }\end{array}$ & Ket & $\begin{array}{l}\text { Pearson } \\
\text { Correlation }\end{array}$ & rTabel & Ket \\
\hline Kinerja puskesmas & 0,60 & 0,604 & Reliabel & $0.219-0.525$ & 0,179 & Valid \\
\hline $\begin{array}{l}\text { Pengelolaan keuangan } \\
\text { BLUD }\end{array}$ & 0,60 & 0,927 & Reliabel & $0.404-0.698$ & 0,179 & Valid \\
\hline Kualitas SDM & 0,60 & 0,828 & Reliabel & $0.430-0.592$ & 0,179 & Valid \\
\hline $\begin{array}{l}\text { Pemanfaatan sistem } \\
\text { informasi }\end{array}$ & 0,60 & 0,780 & Reliabel & $0.190-0.675$ & 0,179 & Valid \\
\hline Pegendalian Internal & 0,60 & 0,684 & Reliabel & $0.179-0.400$ & 0,179 & Valid \\
\hline
\end{tabular}

Sumber: Data Olahan , 2020

Dari Tabel 3 dapat dilihat bahwa hasil uji reliabilitas dengan nilai koefisien Cronbach Alpha>0,60. Hasil uji validitas telah dilakukan dan ditemukan valid dengan masing-masing butir pernyataan di atas kriteria 0,1793 ( $r$ tabel).

\section{Hasil Uji Regresi Berganda}

Analisis regressi berganda dilakukan setelah semua syarat uji asumsi klasik yaitu uji normalitas, heteroskedastisitas dan multikolinieritas terpenuhi. Hasil analisis regressi berganda dapat dilihat pada tabel berikut.

Tabel 4. Hasil Uji Regresi Linier Berganda Multiple Regression Analysis

\begin{tabular}{lcrrrrr} 
& \multicolumn{2}{c}{ Unstandardized Coefficients } & \multicolumn{2}{c}{ Standardized Coefficients } & T & Sig. \\
\cline { 2 - 5 } & B & Std. Error & Beta & & & \\
\hline (Constant) & 3.210 & 1.311 & .448 & .016 \\
Keuangan BLUD & .090 & .022 & .348 & 4.068 & .000 \\
Kualitas SDM & .103 & .030 & .300 & 3.448 & .001 \\
Sistem Informasi & .117 & .032 & .262 & 3.662 & .000 \\
\hline
\end{tabular}

a. Dependent Variable: Kinerja Puskesmas (Y)

Sumber : Data Olahan, 2020

Berdasarkan hasil analisis regresi linier barganda Multiple Regression Analysis pada Tabel 4 Dapat dijelaskan masing-masing uji hipotesis sebagai berikut

\section{Pengelolaan Keuangan BLUD berpengaruh positif terhadap Kinerja Puskesmas}

Hasil pengujian Hipotesis $1\left(\mathrm{H}_{1}\right)$ menemukan nilai t sebesar $4.068(>1.64)$ dengan nilai p sebesar 0.000 $(<0.05)$ nilai $\beta$ (unstandardized) positif, artinya pengelolaan keuangan BLUD berpengaruh positif terhadap kinerja puskesmas. Dengan demikian maka $\mathrm{H}_{1}$ diterima. Hal ini menunjukkan bahwa kinerja puskesmas BLUD dikota Pekanbaru dipengaruhi oleh pengelolaan keuangan BLUD. Semakin baik pengelolaan keuangan BLUD semakin baik kinerja puskesmas BLUD dikota Pekanbaru 
Restianto (2015) menyatakan organisasi sektor publik yang menerapkan pengelolaan keuangan BLUD membuat perjanjian kinerja, dapat memberikan penghargaan kepada pegawai berupa pemberian remunerasi yang didasarkan pada indikator kinerja, serta pengadaan barang dan jasa yang tidak mengikuti Peraturan Presiden (Perpres) yaitu nerdasarkan atas kebijakan pimpinan BLUD. Hal ini dapat mempengaruhi pimpinan atau pegawai dalam meningkatkan kinerjanya. Jadi dengan adanya BLUD ini, maka pengelolaan keuangan di puskesmas dapat dilakukan secara mandiri sehingga puskesmas bisa menyusun anggarannya sendiri sesuai kebutuhan.

Hasil penelitian ini sejalan dengan penelitian yang dilakukan oleh (Winda, 2019) dan (Catherine, 2016) yang mengungkapkan hasil bahwa pengelolaan keuangan BLUD memiliki pengaruh positif terhadap kinerja puskesmas BLUD.

\section{Kualitas SDM berpengaruh positif terhadap Kinerja Puskesmas}

Hasil pengujian Hipotesis $2\left(\mathrm{H}_{2}\right)$ menemukan nilai t sebesar 3.448(>1.64) dengan nilai p sebesar 0.001 $(<0.05)$ nilai $\beta$ (unstandardized) sebesar 0.103 nilai $\beta$ positif, artinya kualitas SDM berpengaruh positif terhadap kinerja puskesmas. Dengan demikian maka $\mathrm{H}_{2}$ diterima. Semakin bagus kualitas SDM yang dimiliki puskesmas maka akan baik kinerja puskesmas BLUD dikota Pekanbaru.

Menurut Matutina (2001) Kualitas SDM yang baik sangat diperlukan dimana pegawai yang berkualitas yaitu pegawai yang memiliki pengetahuan knowledge, keterampilan skill, dan abilities dapat menyelesaikan pekerjaannya dengan baik, sehingga akan berimplikasi terhadap peningkatan kinerja. Hasil penelitian ini sejalan dengan penelitian yang dilakukan oleh (Wicaksono, 2011) dan (Noor, 2015) yang mengungkapkan hasil bahwa kualitas SDM memiliki arah pengaruh positif terhadap kinerja puskesmas BLUD.

\section{Pengaruh Sistem Informasi berpengaruh positif terhadap Kinerja Puskesmas}

Hasil pengujian Hipotesis $3\left(\mathrm{H}_{3}\right)$ menemukan nilai t sebesar $3.662(>1.64)$ dengan nilai p sebesar 0.000 $(<0.05)$ nilai $\beta$ (unstandardized) sebesar 0.117 nilai $\beta$ positif, artinya pemanfaatan sistem informasi berpengaruh positif terhadap kinerja puskesmas. Dengan demikian maka $\mathrm{H}_{3}$ diterima artinya, Semakin bagus pemanfaatan sistem informasi di puskesmas maka akan baik kinerja puskesmas BLUD dikota Pekanbaru

Menurut Loudon dan Kenneth (2015) pemanfaatan sistem informsi yang meliputi teknologi komputer dan teknologi komunikasi dalam proses bisnis akan meningkatkan pemprosesan transaksi dan data lainnya, keakurasian dalam perhitungan, serta penyiapan laporan keuangan dan output lainnya lebih tepat waktu, dengan kata lain pemanfaatan teknologi informasi yang baik akan meningkatkan kualitas pengambilan keputusan, memperbaiki kinerja dan meningkatkan keuntungan perusahaan. Hasil penelitian ini sejalan dengan penelitian (Susanti, 2014), (Fiqra et al., 2016) dan (Wardani, 2018) yang mengungkapkan hasil bahwa pemanfaatan sistem informasi memiliki arah pengaruh positif terhadap kinerja puskesmas.

\section{Hasil Uji Moderated Regresi Analysis (MRA)}

Moderasi Pengendalian Internal terhadap hubungan Pengelolaan Keuangan BLUD dengan Kinerja Puskesmas BLUD di Kota Pekanbaru

Determinan Kinerja Sektor Publik: Dimoderasi Sistem Pengendalian Intern pada Puskesmas BLUD 
Hasil pengujian MRA dapat dilihat pada tabel berikut.

Tabel 5. Hasil Uji Moderasi

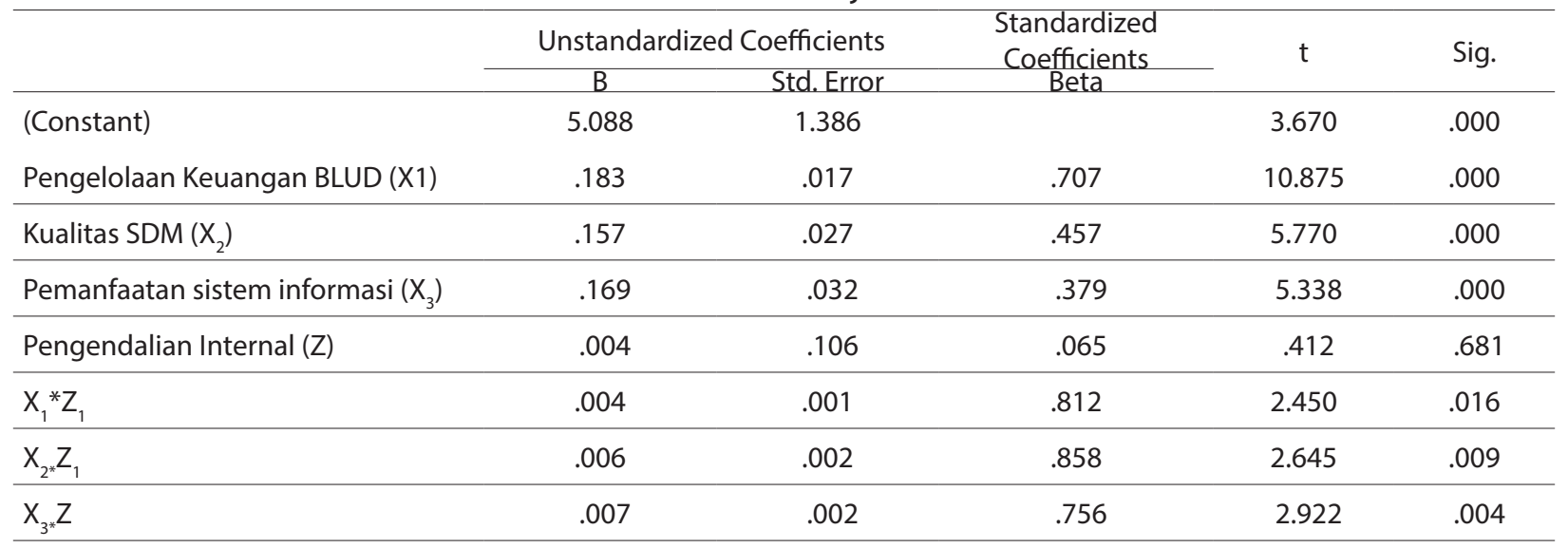

a. Dependent Variable: Kinerja Puskesmas (Y)

Sumber : Data Olahan, 2020

\section{Pengaruh moderasi pengendalian internal terhadap hubungan pengelolaan keuangan BLUD dengan kinerja Puskesmas BLUD di Kota Pekanbaru}

Berdasarkan tabel 5 membuktikan hasil terhadap hipotesis $4\left(\mathrm{H}_{4}\right)$ menunjukkan moderasi sistem pengendalian intern terhadap hubungan pengelolaan keuangan BLUD dengan kinerja Puskesmas di Kota Pekanbaru menunjukkan nilai p value 0.016 (<0.05) dengan nilai t sebesar 2.450 (> 1.6) Dengan demikian $\mathrm{H}_{4}$ Diterima. Nilai $\beta$ positif, artinya variabel pengelolaan keuangan BLUD berpengaruh positif terhadap kinerja puskesmas jika dimoderasi oleh pengendalian internal. Adanya pengendalian intern dapat meningkatkan pengelolaan BLUD dan berdampak pada peningkatan kinerja Puskesmas BLUD.

Dalam hal ini pengendalian intern merupakan Quasi Moderator (Moderator semu) ditunjukkan dengan Nilai $\beta$ (unstandardized) $\beta 2 \neq 0$ dan $\beta 3 \neq 0$, artinya selain sebagai variabel moderator, pengendalian intern juga berperan sebagai variabel independen.

Pengendalian internal merupakan faktor lain yang dapat memperkuat atau memperlemah hubungan antara pengelolaan keuangan BLUD dan kinerja Puskesmas BLUD dikota Pekanbaru. Menurut (Restianto, 2015) pengelolaan keuangan BLUD menjelaskan fleksibilitas berupa keleluasan pengelolaan pendapatan dan belanja. Puskesmas dapat secara bebas atau langsung dapat menggunakan pendapatannya sesuai dengan kebutuhan saat itu dengan tetap berdasarkan Rencana Anggaran Biaya. Oleh karena itu dengan adanya pemberian kewenangan dan keleluasaan dalam mengelola keuangan, agar tidak terjadi penyimpangan dan penyelewengan tersebut harus diikuti dengan pengawasan, pengendalian internal yang kuat.

Ini sejalan dengan penelitian (Misfikar, 2018) yang mengungkapkan hasil bahwa pengendalian internal mampu menjadi variabel pemoderasi antara hubungan pengelolaan keuangan BLUD dengan kinerja puskesmas. 


\section{Pengaruh moderasi pengendalian internal terhadap hubunganKualitas SDM dengan kinerja Puskesmas BLUD di Kota Pekanbaru}

Berdasarkan tabel 5 membuktikan hasil terhadap hipotesis $5\left(\mathrm{H}_{5}\right)$ Dengan nilai t sebesar $2.645(>1.64)$, nilai P sebesar $0.009(<0.05)$, nilai $\beta$ (unstandardized) positif.artinya variabel kualitas SDM berpengaruh positif terhadap kinerja puskesmas jika dimoderasi oleh pengendalian internal. Dengan demikian $\mathrm{H}_{5}$ diterima. Hal ini menunjukkan bahwa pengendalian intern dapat meningkatkan kompetensi individu dalam melaksanakan tugasnya sehingga dapat meningkatkan kinerja puskesmas.Hasil analisis menunjukkan posisi pengendalian intern adalah sebagai Quasi Moderator (Moderator semu) yang ditunjukkan dengan $\beta 2 \neq 0$ dan $\beta 3 \neq 0$.

(Noor, 2015) menjelaskan SDM merupakan pilar penyangga utama sekaligus penggerak roda organisasi dalam usaha mewujudkan visi dan misi serta tujuan dari organisasi tersebut. Karena itu, sangat penting dalam menyeleksi kualitas SDM yang akan di rekrut untuk mengelola keuangan, maka untuk menentukan dan menyeleksi kualitas SDM tersebut harus diikuti dengan pengendalian internal yang kuat. Penguatan fungsi pengendalian dilakukan dengan melalui pembuatan sistem pengendalian internal mengenai seleksi kualitas SDM. Oleh karena itu $\mathrm{H}_{5}$ yang menyatakan pengendalian internal dapat memoderasi hubungan kualitas SDM terhadap kinerja puskesmas dapat diuji dan hipotesis ini tidak perlu dieliminasi.

\section{Pengaruh moderasi Pengendalian Internal terhadap hubungan Pemanfaatan Sistem Informasi dengan Kinerja Puskesmas BLUD di Kota Pekanbaru}

Berdasarkan tabel 5 membuktikan hasil terhadap hipotesis $6\left(\mathrm{H}_{6}\right)$ Dengan nilai t sebesar $2.922(>1.64)$ nilai P sebesar $0.004(<0.05)$ nilai $\beta$ positif. Artinya variabel pemanfaatan sistem informasi berpengaruh positif terhadap kinerja puskesmas jika dimoderasi oleh pengendalian internal. Dengan demikian $\mathrm{H}_{6}$ Diterima. Hasil analisis menunjukkan bahwa dengan adanya pengendalian intern maka dapat meningkatkan pemanfaatan sistem informasi pada puskesmas sehingga akan berdampak pada peningkatan kinerja puskesmas. Variabel moderasi pada pengujian ini memiliki posisi sebagai Quasi Moderator (Moderator semu) yang ditunjukkan dengan nilai $\beta$ (unstandardized) $\beta 2 \neq 0$ dan $\beta 3 \neq 0$.

Berdasarkan Peraturan Pemerintah Republik Indonesia No. 60 Tahun 2008 tentang Sistem Pengendalian Intern Pemerintah untuk optimalisasi pemanfaatan teknologi informasi harus didukung dengan sistem pengendalian intern yang baik, hal ini dikarenakan biaya yang dikeluarkan yang cukup besar dan tidak murah serta pemanfaatannya yang harus sesuai untuk menghindari penyalahgunaan. Secanggih apapun teknologi informasi yang dimliki, apabila tidak adanya pengendalian internal yang baik maka hasilnya akan sia-sia. Oleh karena itu $\mathrm{H}_{6}$ yang menyatakan pengendalian internal dapat memoderasi hubungan pemanfaatan sistem informasi terhadap kinerja puskesmas dapat diuji dan hipotesis ini tidak perlu dieliminasi.

\section{PENUTUP}

Hasil pengujian menunjukan bahwa pengelolaan keuangan BLUD, kualitas SDM dan pemanfaatan sistem informasi secara parsial berpengaruh positif terhadap kinerja puskesmas BLUD dikota Pekanbaru. Hal ini berarti dengan adanya pengelolaan keuangan BLUD, kualitas SDM dan pemanfaatan sistem informasi puskesmas BLUD dikota Pekanbaru dapat mengoptimalkan kinerja puskesmas di kota Pekanbaru.

Determinan Kinerja Sektor Publik: Dimoderasi Sistem Pengendalian Intern pada Puskesmas BLUD 
Selanjutnya berdasarkan hasil uji Moderated Regression Analysis menunjukkan bahwa pengendalian internal memperkuat hubungan pengelolaan keuangan BLUD, kualitas SDM dan sistem informasi terhadap kinerja puskesmas. Dengan adanya sistem pengendalian intern yang baik maka dapat meningkatkan pengelolaan BLUD, kompetensi SDM serta pemanfaatan teknologi informasi yang berdampak pada peningkatan kinerja puskesmas BLUD di Kota Pekanbaru.

Penelitian ini tentunya memiliki keterbatasan yaitu memiliki lingkup hanya puskesmas di Kota Pekanbaru sehingga tidak dapat digeneralisasi pada daerah yang lebih luas. Selain itu penelitian ini juha hanya meneliti 3 variabel independe yaitu pengelolaan BLUD, kompetensi SDM dan pemanfaatan teknologi informasi. Oleh sebab itu peneliti selanjutnya disarankan agar dapat menggunakan instrumen penelitian lainnya (selain kuesioner), menggunakan variabel lain yang diasumsikan dapat mempengaruhi kinerja puskesmas, misalnya kepemimpinan, budaya organisasi dll.

Hasil dari penelitian ini mempunyai implikasi kepada organisasi sektor publik yang menerapkan pengelolaan keuangan BLUD agar dapat mengoptimalkan pengelolaan keuangan BLUD, kualitas SDM, pemanfaatan sistem informasi dan pengendalian internal untuk pencapaian kinerja.

\section{DAFTAR PUSTAKA}

Anggarini, Y., \& Puranto. H., (2010). Anggaran Berbasis Kinerja Penyusunan APBD Secara Komprehensif (Yogyakarta). Sekolah Tinggi Manajemen YKPN.

Areva, D. (2012). Analisis Pengukuran Kinerja Dengan Sistem Balanced Scorecard Pada Rumah Sakit Yos Sudarso Padang. ECONOMICA, 1(1).

Asse, A. (2016). Analisis Kinerja Pengelolaan Keuangan BLUD RSUD Kabupaten Nunukan.

Budiarso, N., Tinangon, J., \& Rondonuwu, R. (2015). Analisis Efisiensi dan Efektivitas Pengelolaan Keuangan Daerah pada Dinas Pendapatan Daerah Kabupaten Minahasa. Jurnal Riset Ekonomi, Manajemen, Bisnis Dan Akuntansi, 3(4), 23-32.

Catherine, L. R. (2016). Evaluasi Kinerja Puskesmas Yang Menerapkan Pengelolaan Keuangan BLUD (Studi Pada Puskesmas BLUD Balik Papan). UGM.

Ernitati. (2016). Analisis Kinerja Univeristas yang Berstatus Badan Layanan Umum (BLU). Jurnal Pendidikan Ekonomi Dan Bisnis, 8(1), 44-52.

Fahdi, M., Sari, R. N., \& Rasuli, M. (2015). Faktor-Faktor Yang Mempengaruhi Kinerja Satuan Kerja Badan Layanan Umum Universitas Riau. Jurnal Akuntansi, 4(1), 101-113.

Fiqra, N., Ulfah, Y., \& Setiawaty, A. (2016). Pengaruh Pemanfaatan Teknologi Informasi dan Pengendalian Intern Terhadap Kinerja Instansi. JIAM-Junral IImu Akuntansi Mulawarman, 1(1), 25-33.

Hendra, J. (2018). Pengaruh Partisipasi Dalam Penganggaran dan Peran Manajerial Pengelola Keuangan Daerah Terhadap Kinerja Pemerintah Daerah. 2(1), 8-17.

Lamusu, L. (2013). Pengaruh Sistem Pengendalian Intern Pemerintah Terhadap Efektivitas Pengelolaan Keuangan Dearah Pada PPKAD Kab. Gorontalo. Universitas Negeri Gorontalo, 1-11.

Liawan, C. (2018). Analisis Penggunaan dana Badan Layanan Umum Daerah (BLUD) Pada Rumah Sakit Umum 
Daerah Sele Be Solu Kota sorong. Jurnal Pitis AKP, 2(1), 27-38. https://doi.org/10.32531/jakp.v3i1.89

Loudon Jane. P., \& Kenneth C. (2015). Sistem Informasi Manajemen, Mengelola Perusahaan Digital (Edisi 13).

Salemba Empat.

Mahsun, M. (2016). Pengukuran Kinerja Sektor Publik. BPFE-Yogyakarta.

Matutina. (2001). Manajemen Sumber Daya Manusia (Cetakan Ke). Gramedia widia.

Misfikar. (2018). Pengaruh Pengalolaan Keuangan BLUD Terhadap Kinerja Organisasi Dengan Pengendalian Internal Sebagai Variabel Moderasi. Universitas Riau.

Noor, A. S. dan D. H. S. (2015). Kinerja UPT Dinas Kesehatan Setelah Penerapan Pengelolaan Keuangan BLUD (Studi Kasus Pada Puskesmas Seyegan). UGM.

Nurani, A., Mutia Basri, Y., \& Novita, I. (2020). Determinants of The Quality of Public Sector Financial Statements: Study at The University in Riau Province Abstract : 6.

Oktari, R. dan A. N. (2011). Pengaruh Pemnfaatan Teknologi Informasi Dan pengendalian Internal Terhadap Kinerja Instansi Pemerintah (Studi Pada Satuan Kerja Perangkat Daerah Kab. Kampar). Universitas Riau.

padma dewi, ni. (2014). Penilaian Kinerja Berdasarkan Ukuran Keuangan Dan Non-Keuangan Rumah Sakit Umum Daerah Wangaya. E-Jurnal Akuntansi, 7(3), 761-777.

Puspadewi, F. (2015). Analisis Implementasi Pengelolaan Keuangan Blud Dan Dampaknya Terhadap Kinerja Pada Rumah Sakit Umum Daerah Nganjuk. Dk, 53(9), 1689-1699. https://doi.org/10.1017/ CBO9781107415324.004

Ratih, Utami Hidayati, I. N. (2011). Evaluasi Kinerja Keuangan Rumah Sakit Umum Daerah (Perbandingan Sebelum dan Sesudah BLUD ). UGM.

Restianto, Y. E. dan I. R. B. (2015). Pengelolaan Keuangan BLU/BLUD. STIM YKPN.

Rulyanti, D., Sularso, R. A., \& Sayekti, Y. (2018). Faktor-Faktor Yang Mempengaruhi Kinerja Pemerintah Desa Melalui Pengelolaan Keuangan Desa Sebagai Variabel Intervening. Bisma, 11(3), 323. https://doi. org/10.19184/bisma.v11i3.6474

Sukesti, F. (2010). Analisis Penggunaan Balanced Scorecard Sebagai Alternatif Untuk Mengukur Kinerja Pada Universitas Muhammadiyah Semarang. Prosiding Seminar Nasional UNIMUS, 416-424.

Sulina, G. A. T., Wahyuni, M. A., \& Kurniawan, P. S. (2017). Peranan Sistem Keuangan Desa (SISKEUDES) Terhadap Kinerja Pemerintah Desa ( Studi Kasus di Desa Kaba-kaba, Kecamatan Kediri, Kabupaten Tabanan ) e-Journal S1 Ak Universitas Pendidikan Ganesha. Jurnal Akuntansi, 1(2).

Susanti, I. (2014). Pengaruh Good Governance, Pemanfaatan Teknologi Informasi dan Pengendalian Intern terhadap Kinerja Organisasi (Studi pada Skpd Kabupaten Siak). Jurnal Online Mahasiswa Fakultas Ekonomi Universitas Riau, 1(1), 1-14.

Wardani, O. C. (2018). Analisis dan Evaluasi Kinerja Sistem Informasi Puskesmas (SIMPUS) untuk Meningkatkan Kinerja Karyawan pada Puskesmas Trogosari Wetan. Universitas Dian Nuswantoro Semarang.

Wicaksono, H. (2011). Analisis Hubungan Kualitas SDM PNS dan Kinerja Pemerintah Kab. Madium. Universitas Sebelas Maret.

Winda, A. T. S. H. (2019). Analisis Kinerja BLUD (Studi Pada Puskesmas Kutoarjo). Universitas Sanata Dharma.

Determinan Kinerja Sektor Publik: Dimoderasi Sistem Pengendalian Intern pada Puskesmas BLUD

Mai Siska, Ria Nelly Sari \& Yesi Mutia Basri Program Studi Magister Akuntansi, Universitas Riau Pekanbaru, Indonesia 